\title{
Compensatory Class III malocclusion treatment associated with mandibular canine extractions
}

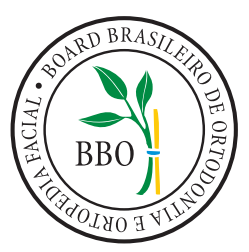

Guilherme Janson¹, Olga Benário Vieira Maranhão

DOI: https://doi.org/10.1590/2177-6709.22.6.086-098.bbo

Skeletal Class III malocclusions are ideally treated with orthodontic-surgical approaches. However, if there are no significant soft tissue implications and the patient does not want to undergo orthognatic surgery, other treatment options may be considered. The current case report describes a compensatory alternative for Class III malocclusion treatment, by means of mandibular canine extractions. This treatment alternative provided facial profile and occlusal improvement, which remains stable seven years posttreatment.

Keywords: Canine extraction. Class III malocclusion. Orthodontics. Corrective.

As más oclusões esqueléticas de Classe III são idealmente tratadas com intervenções ortodôntico-cirúrgicas. Contudo, se não existirem implicações estéticas faciais e se o paciente não desejar se submeter à cirurgia ortognática, outras opções de tratamento podem ser consideradas. O presente caso clínico descreve um tratamento compensatório alternativo para a má oclusão de Classe III, com extrações de caninos inferiores. Esse tratamento alternativo propiciou melhoras no perfil facial e na oclusão, que permaneceu estável após sete anos da sua finalização.

Palavras-chave: Extração de caninos. Má oclusão de Classe III. Ortodontia corretiva.

\section{INTRODUCTION}

Class III is a complex malocclusion that involves dental, skeletal or both structures. ${ }^{1,2}$ Treatment usually consists in a compensatory or orthodontic-surgical approach, ${ }^{3}$ but the results are not always predictable. In cases with great skeletal vertical and anteroposterior discrepancies, the orthodontic treatment associated with a surgical approach might be the best treatment plan. ${ }^{1,4}$ However, in some cases the patient is more interested in less invasive interventions. In these situations, one option is compensatory treatment

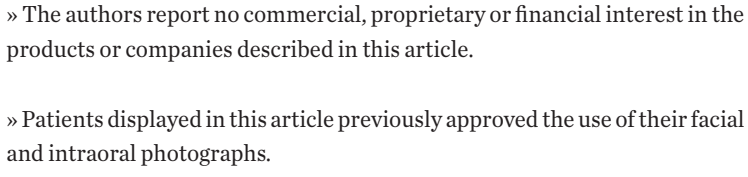

${ }^{1}$ Universidade de São Paulo, Faculdade de Odontologia de Bauru, Departamento de Ortodontia (Bauru/SP, Brasil). with extractions, which also provides good occlusal and acceptable esthetic results, with good stability. ${ }^{5-8}$ A compensatory approach is also indicated when the patient does not have esthetic complaints and the anteroposterior skeletal discrepancy is not severe. ${ }^{9}$

Usually, protocols in compensatory orthodontic treatment involve premolar extractions, but incisor and molar extractions are also described in the literature. ${ }^{8,10,11}$ In this case report, mandibular canine extractions were performed to improve the occlusal relationships and facial esthetics.

\footnotetext{
How to cite: Janson G, Maranhão OBV. Compensatory Class III malocclusion treatment associated with mandibular canine extractions. Dental Press J Orthod. 2017 Nov-Dec;22(6):86-98.

DOI: https://doi.org/10.1590/2177-6709.22.6.086-098.bbo
}

Submitted: August 25, 2017 - Revised and accepted: September 21, 2017

Contact address: Guilherme Janson

E-mail: jansong@travelnet.com.br 


\section{DIAGNOSIS}

A 13-year-old female patient was referred for treatment by her parents after many previous orthodontic assessments. The patient had a skeletal Class III malocclusion pattern and previous treatment plans consisted in surgical-orthodontic approaches. However, her parents did not accept a surgical treatment, and searched for a different opinion with the first author. Almost all of her relatives did not present a skeletal Class III malocclusion pattern, except for her paternal grandfather who had a similar pattern.

The extraoral examination showed a skeletal Class III malocclusion pattern, vertical growth, incompetent lip seal, mouth breathing and lingual thrust during speech and swallowing. Intraorally, she presented with a com- plete bilateral Class III malocclusion, moderate mandibular anterior crowding, mild maxillary anterior crowding, maxillary midline deviated $1.5 \mathrm{~mm}$ to the left, anterior open bite, overjet of $-1 \mathrm{~mm}$, and tonsils hypertrophy (Figs 1 and 2). The panoramic radiograph shows that all teeth were present, with the third molars under development. No other significant abnormality was found (Fig 3).

Cephalometrically, she had a slightly protruded maxilla, mandibular protrusion, a moderate skeletal Class III apical base discrepancy, and an accentuated vertical growth pattern. The maxillary incisors were labially tipped and slightly protruded, and the mandibular incisors were lingually tipped and linearly well positioned (Table 1 and Fig 4).
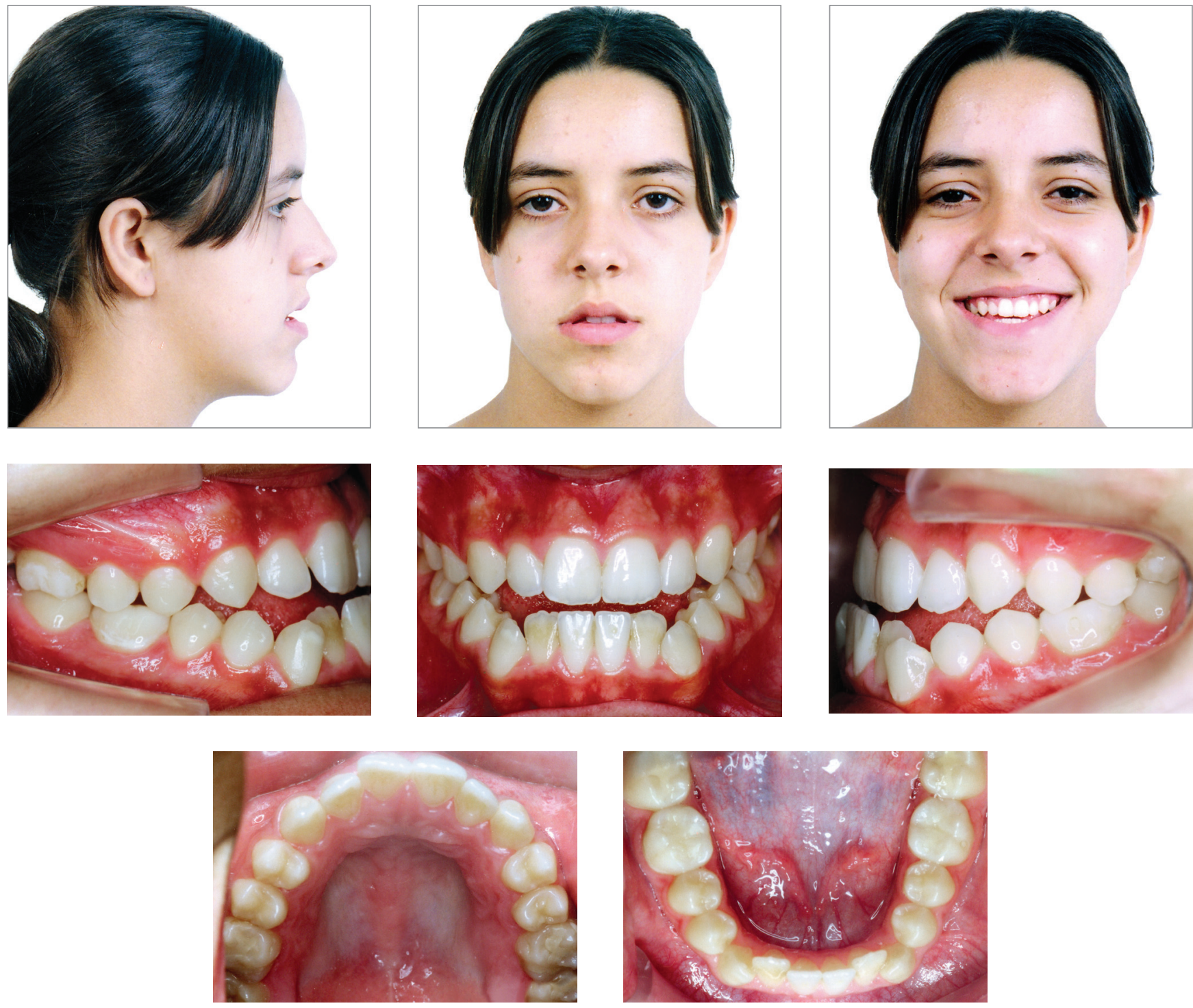

Figure 1 - Initial extra- and intraoral photographs 

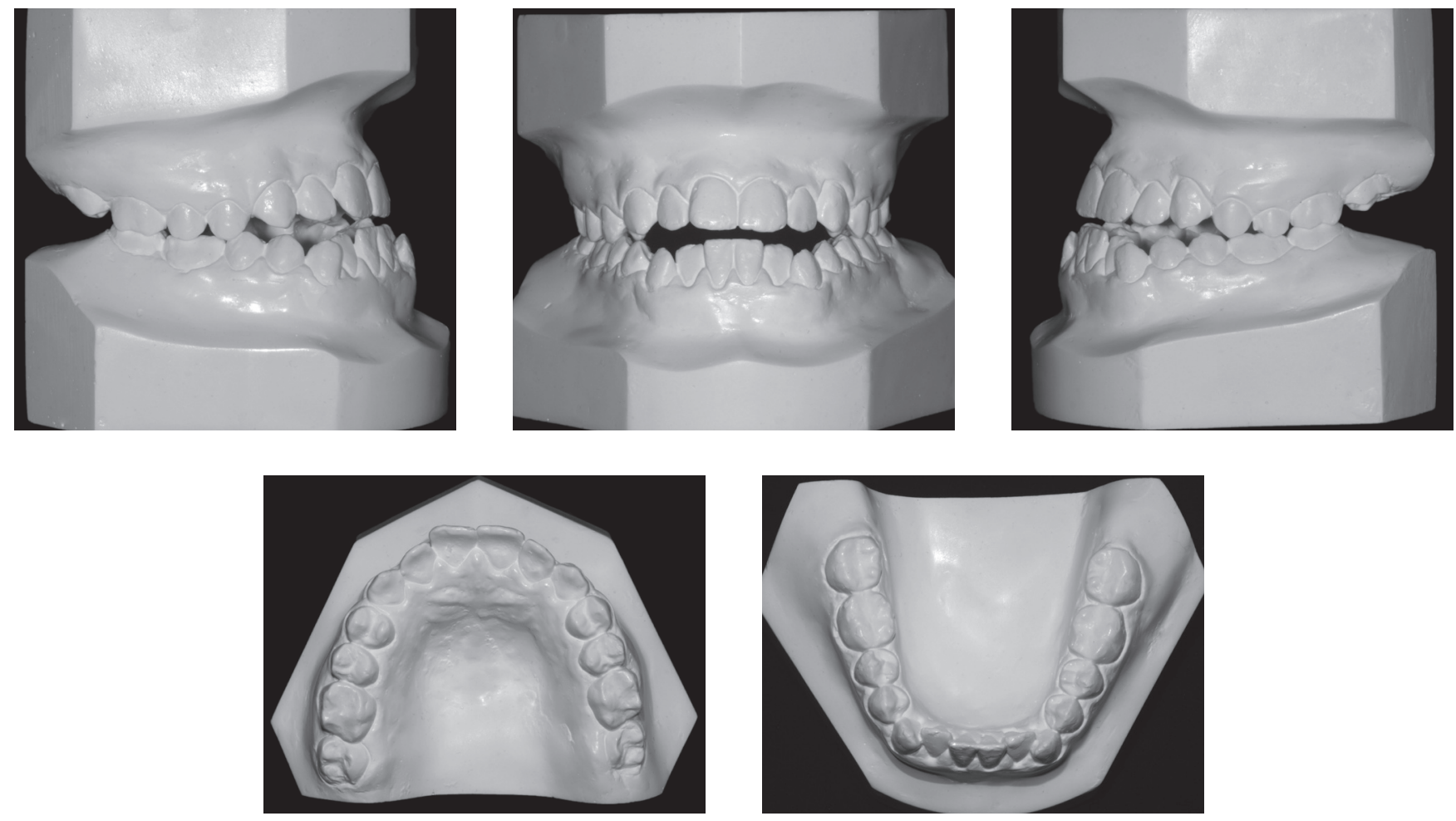

Figure 2 - Initial dental models.

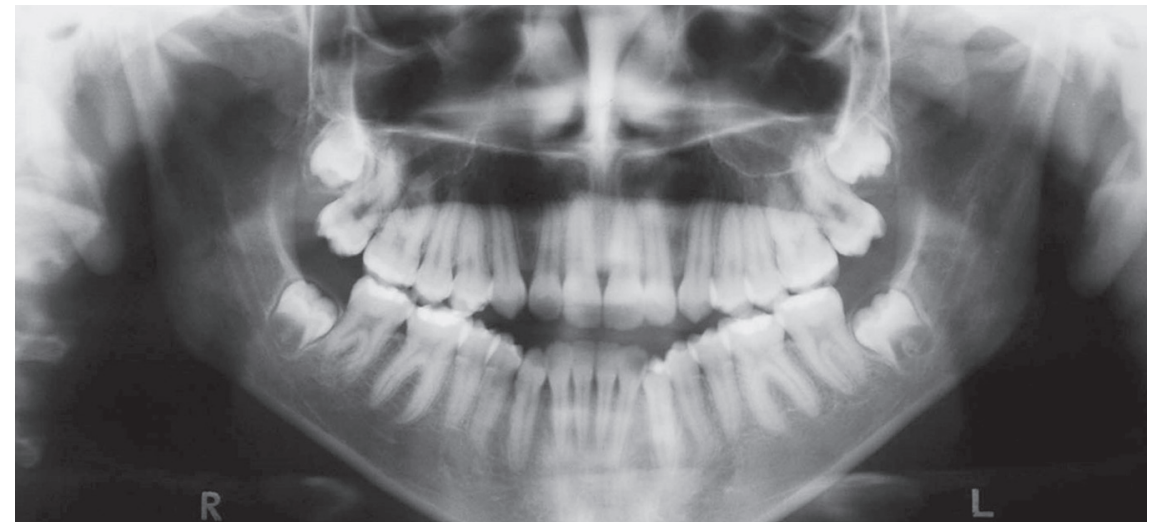

Figure 3 - Initial panoramic radiograph

\section{TREATMENT PLAN}

The treatment plan consisted in performing rapid maxillary expansion followed by maxillary protraction with a facemask. ${ }^{12}$ Extraction of the mandibular canines would be performed to correct the negative overjet. Thereafter, Roth preadjusted appliances would be used, associated with Class III and anterior vertical elastics to complete correction of the anteroposterior and vertical discrepancies, respectively.

\section{TREATMENT PROGRESS}

Treatment was initiated with rapid maxillary expansion, according to Liou's protocol, ${ }^{13}$ which consists in activating the expander $1 \mathrm{~mm}$ per day, during 5 days, followed by closing the expander $1 \mathrm{~mm}$ per day, during 5 additional days. This procedure was repeated for three times (Fig 5). After the expansion, a facemask was installed to protract the maxilla, recommended to be used for 12 hours a day, with a force of $400 \mathrm{~g}$ (Fig 6). 


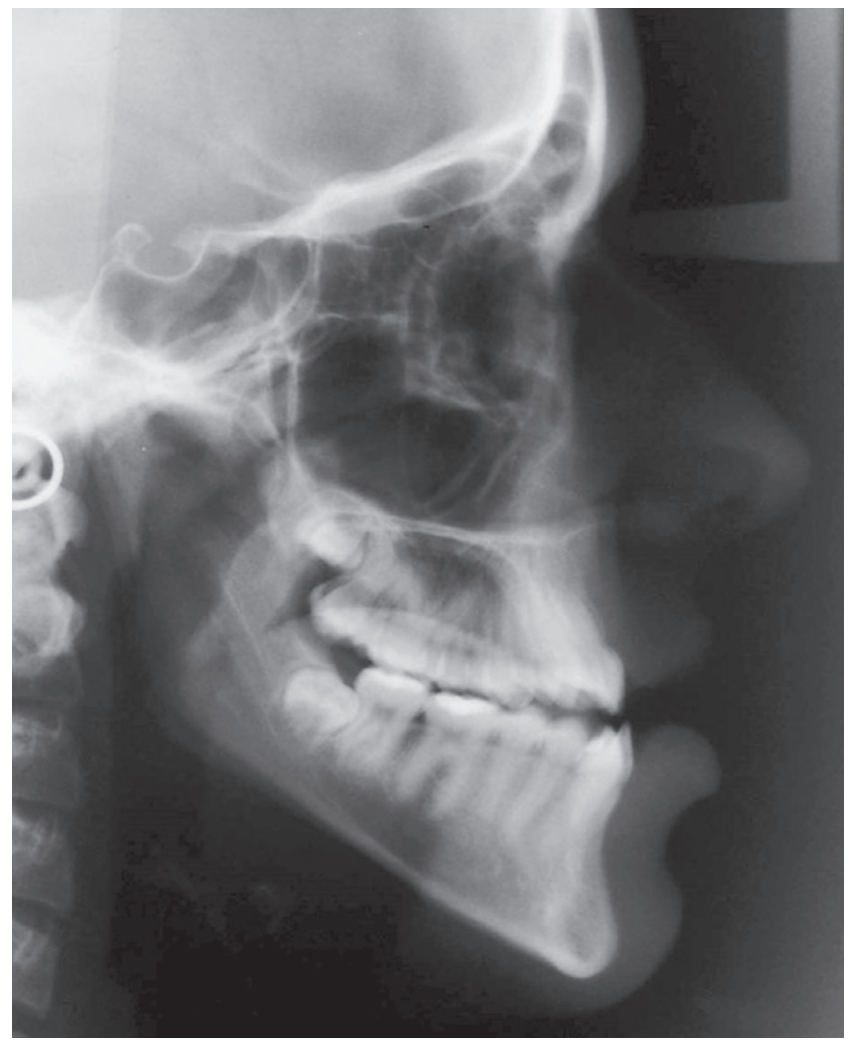

Figure 4 - Initial cephalogram.
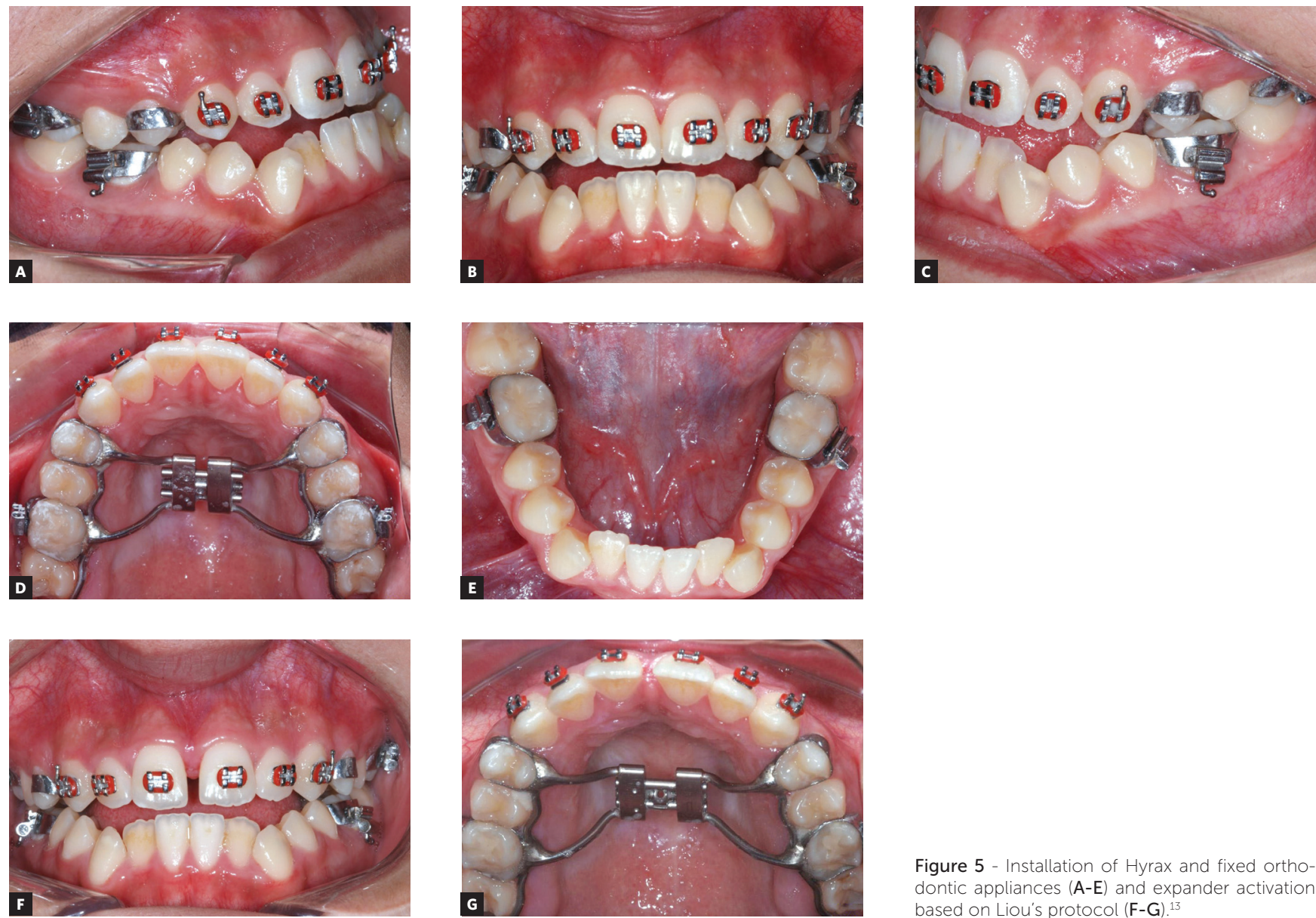

Figure 5 - Installation of Hyrax and fixed orthodontic appliances (A-E) and expander activation based on Liou's protocol (F-G) ${ }^{13}$ 

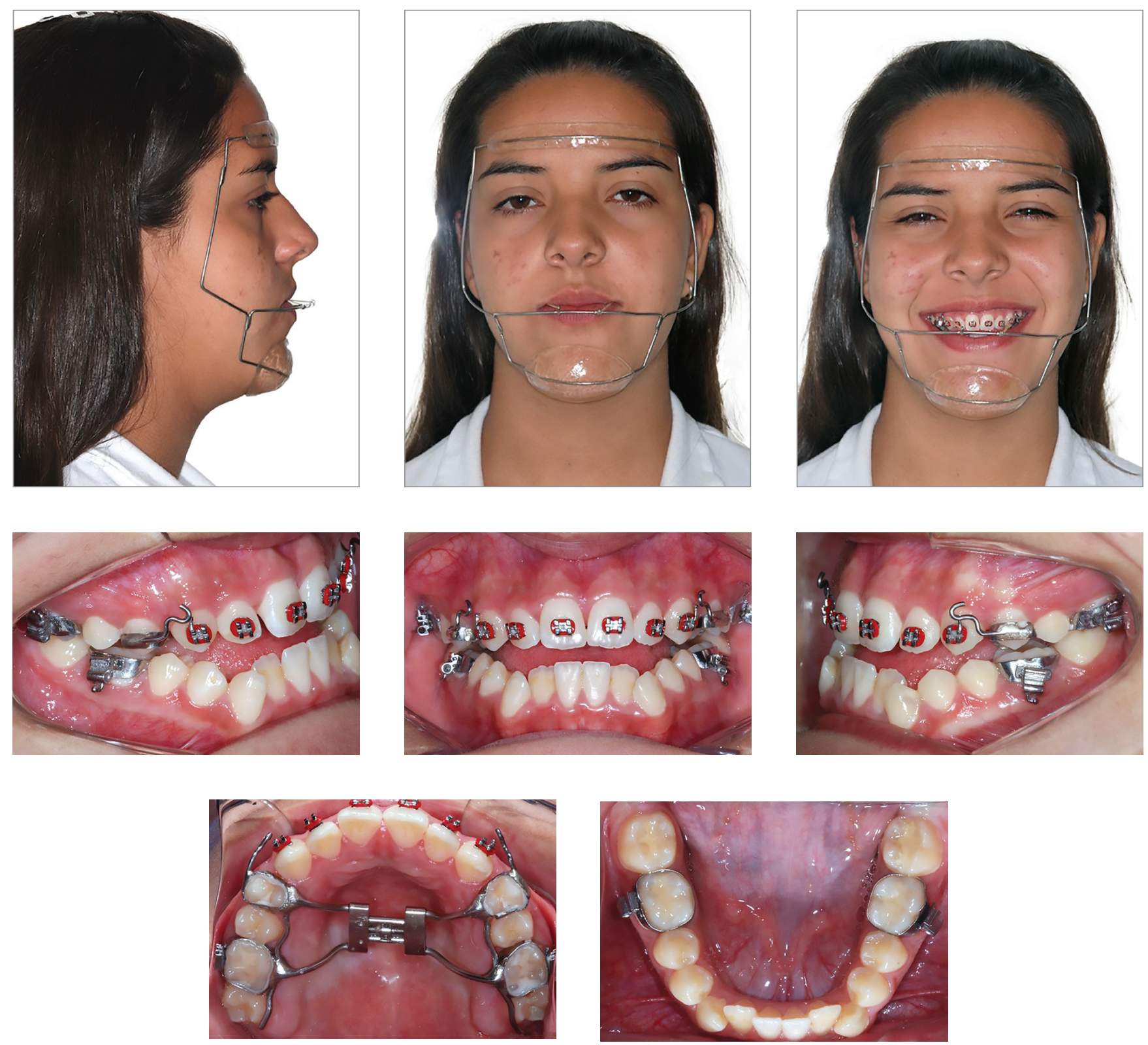

Figure 6 - Facemask installation.

Despite the efforts, there was only small maxillary protraction, positioning the incisors in an edge to edge relationship (Fig 7). Therefore, because of the persisting Class III anteroposterior relationship and the mandibular anterior crowding, the mandibular canines were extracted. At this time, Roth preadjusted appliances installation was completed. Leveling and alignment proceeded with 0.014 and 0.016 -in NiTi archwires, followed by 0.016 , 0.018 and 0.020 -inch stainless steel archwires, with a hook on the distal of the mandibular lateral incisors, to engage Class III elastics, used for 18 hours a day, with
$200 \mathrm{~g}$ of force (Figs 7 and 8). Subsequently, rectangular $0.018 \times 0.025$-in archwires were installed to retract the mandibular incisors and to control torque during the use of Class III CS2000 springs (DynaFlex, MO, USA) or elastics (Fig 9). A chin-cup was used during sleeping hours to redirect mandibular growth, during treatment. After retraction of the mandibular incisors, vertical elastics were used to improve interdigitation. The total treatment time was of 3 years and 3 months.

After fixed appliances removal, a Hawley plate was installed in the maxillary arch, and recommended to be 

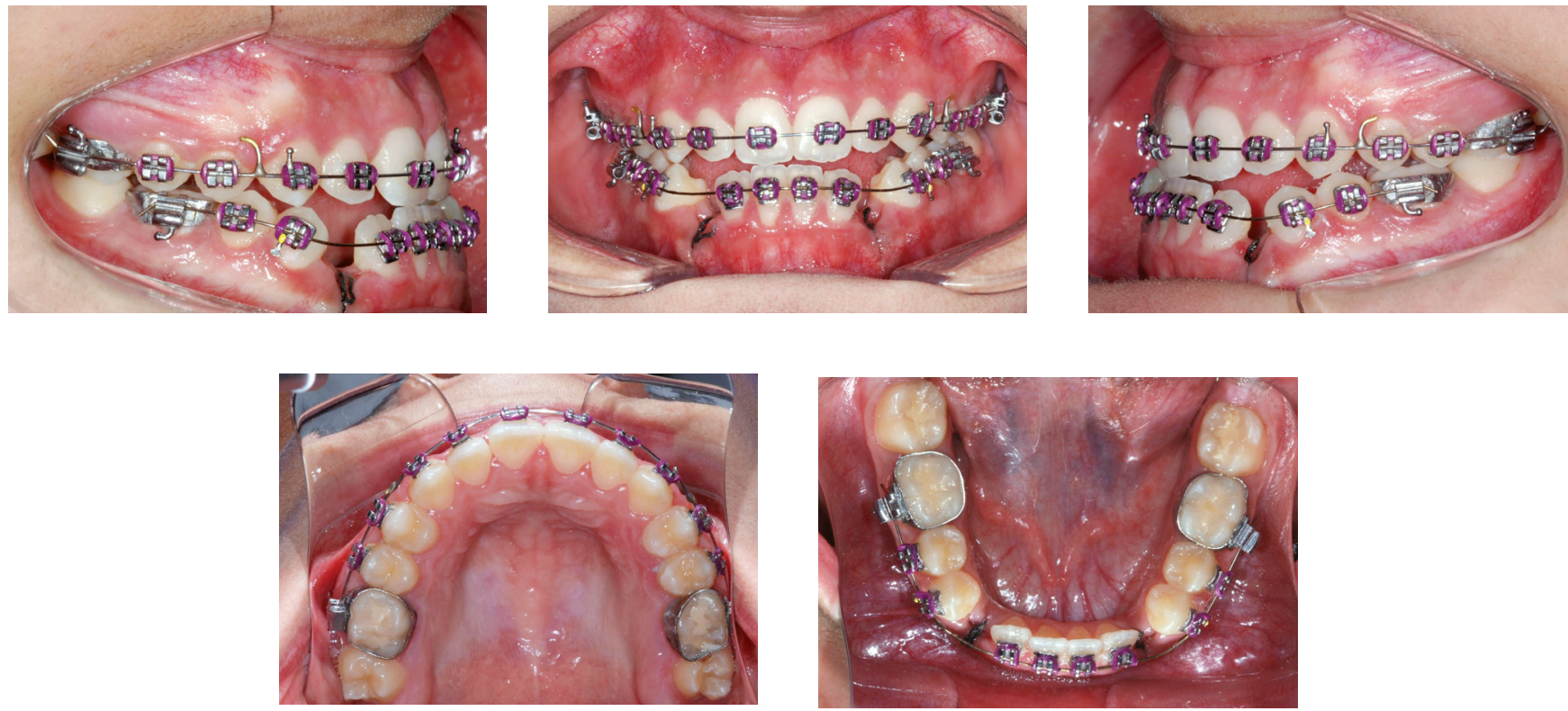

Figure 7 - Intraoral photos of mandibular canine extractions.
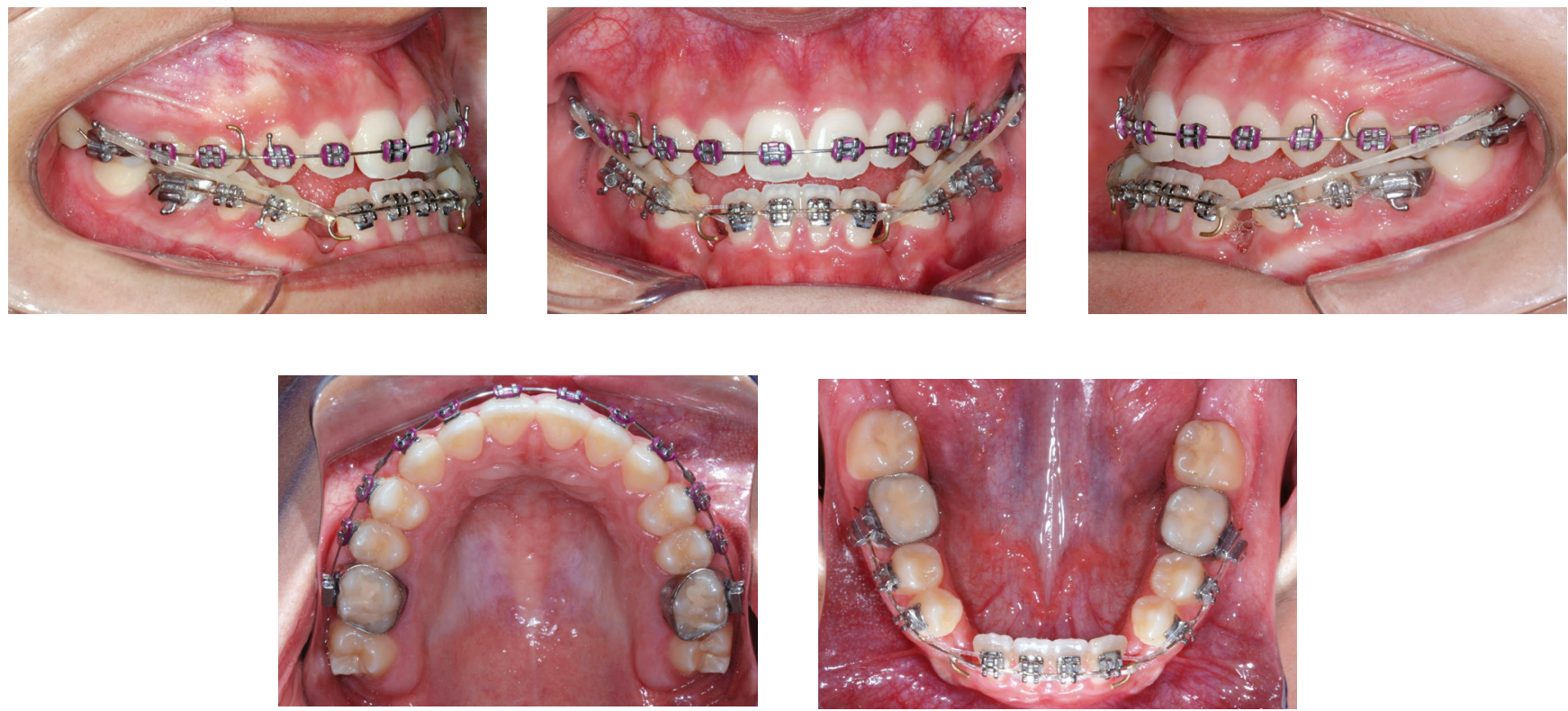

Figure 8 - Mandibular anterior retraction and Class III elastics.
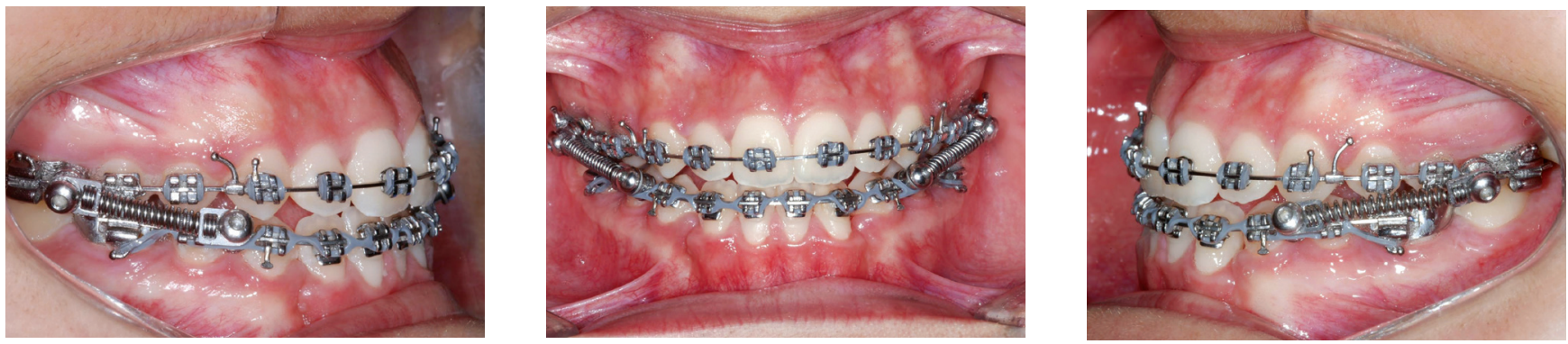

Figure 9 - Mandibular anterior retraction and Class III mechanics with CS 2000 spring (DynaFlex, MO, USA) 

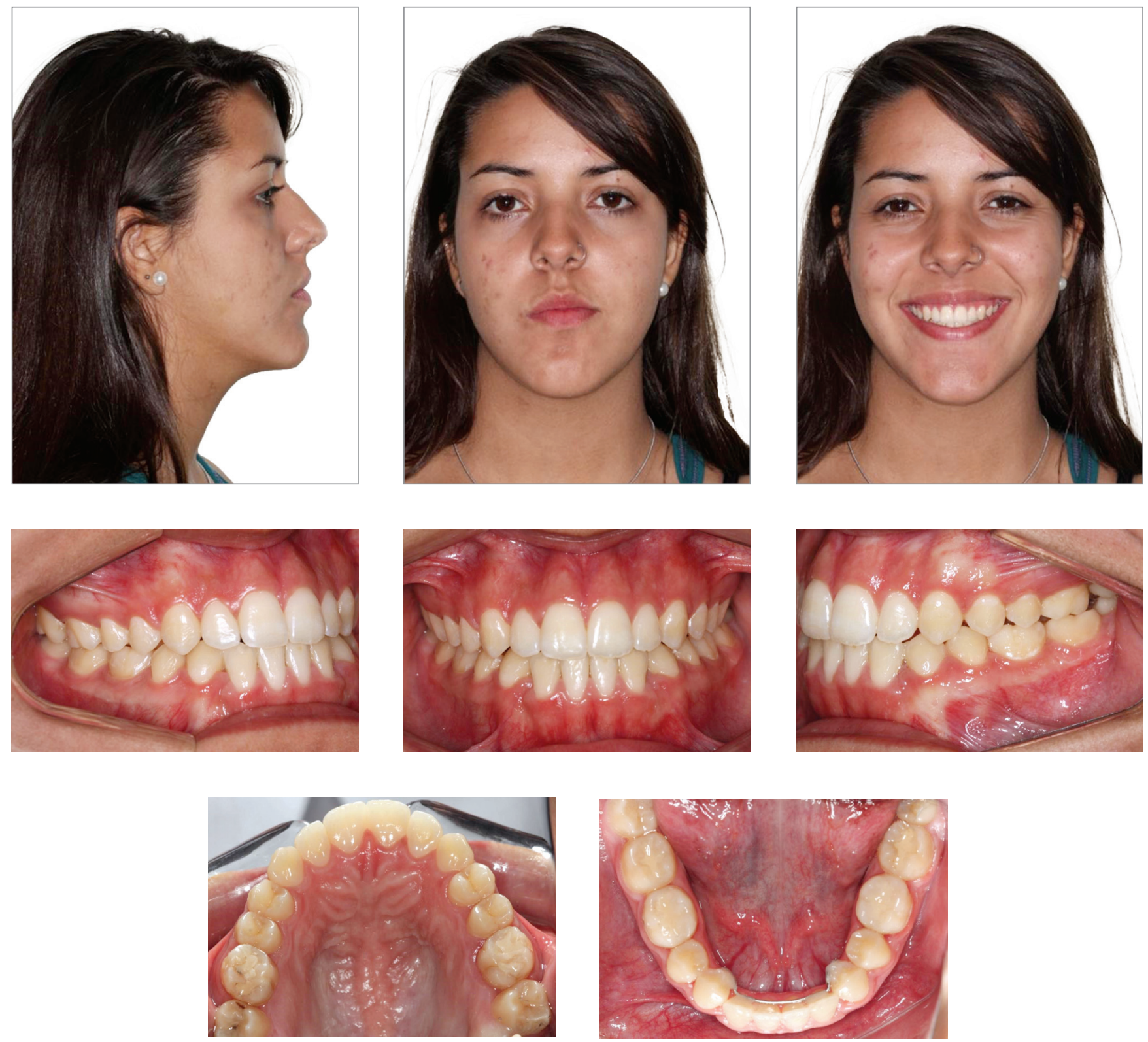

Figure 10 - Final extra- and intraoral photographs.

used 20 hours a day during 6 months; and night time use only, during the following 6 months. In the mandibular arch, a fixed first premolar-to-first premolar retainer was bonded on each tooth and recommended to be used for 3 years. The chin-cup was recommended to be used at night, as active retention, until the end of growth, which is approximately at age $20 .{ }^{14,15}$

\section{TREATMENT RESULTS}

The facial profile improved, showing passive lip seal and improvement of the zygomatic promi- nence (Fig 10). Consequent to crossbite and anterior open bite corrections, there was significant improvement of the smile esthetics (Figs 10 and 11).

Due to slight maxillary protrusion and slight relative mandibular retrusion, there was improvement of the basal anteroposterior relationship, with reduction of the convexity angle (Fig 12 and Table 1). The maxilla had small anterior displacement provided by the facemask, Class III CS2000 springs and elastics, which were the factors that greatly contributed to correct the problem. The mandible experienced relative retrusion. 

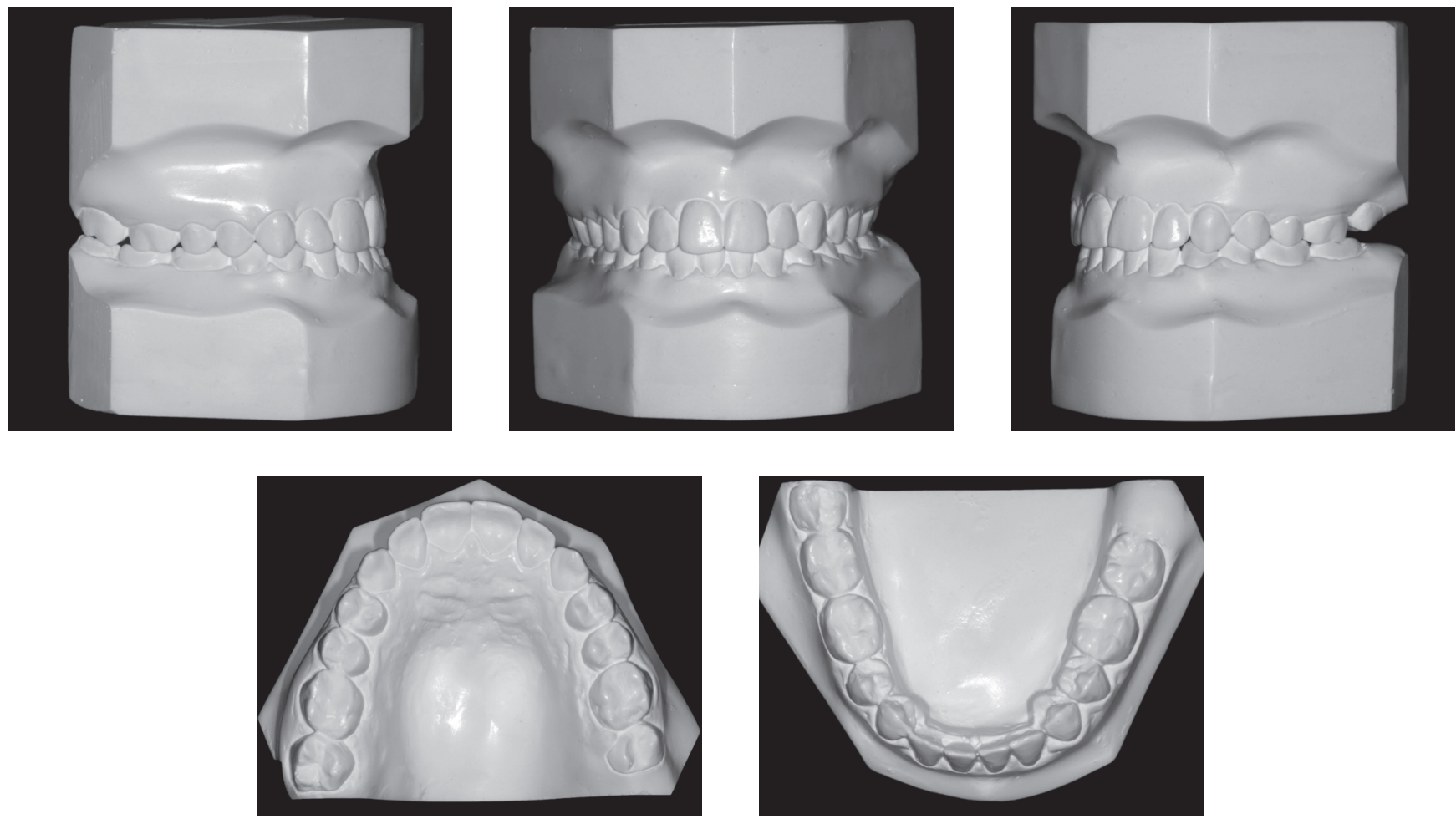

Figure 11 - Final dental models.

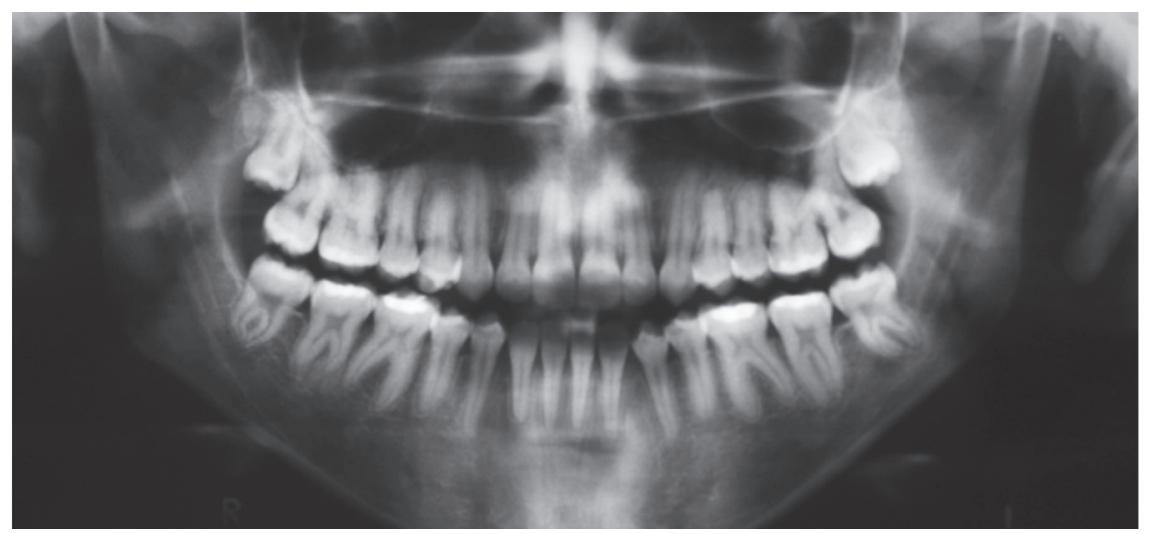

Figure 12 - Final panoramic radiograph

There was correction of the open and anterior crossbites, the maxillary incisors were palatally tipped and protruded and the mandibular incisors were lingually tipped and slightly protruded (Figs 10 to 13, and Table 1). The mandibular first premolars replaced the canines and were positioned in Class I relationship with the maxillary canines, and the molars presented Class III relationship due to extractions of the mandibular canines (Fig 12).

Treatment remained fairly stable 7 years posttreatment, with the patient presenting good facial esthet- ics and occlusal relationships (Figs 14-17 and Table 1). The overjet and overbite are still positive and the transverse relationship is very satisfactory. All teeth are in contact and the third molars are present (Fig 16).

The tracings superimposition show that the anteroposterior basal discrepancy continued to improve (Fig 18 and Table 1). The maxillary incisors had slight palatal tipping and the mandibular incisors had slight labial tipping and protrusion. Molar relationship remained quite stable. 

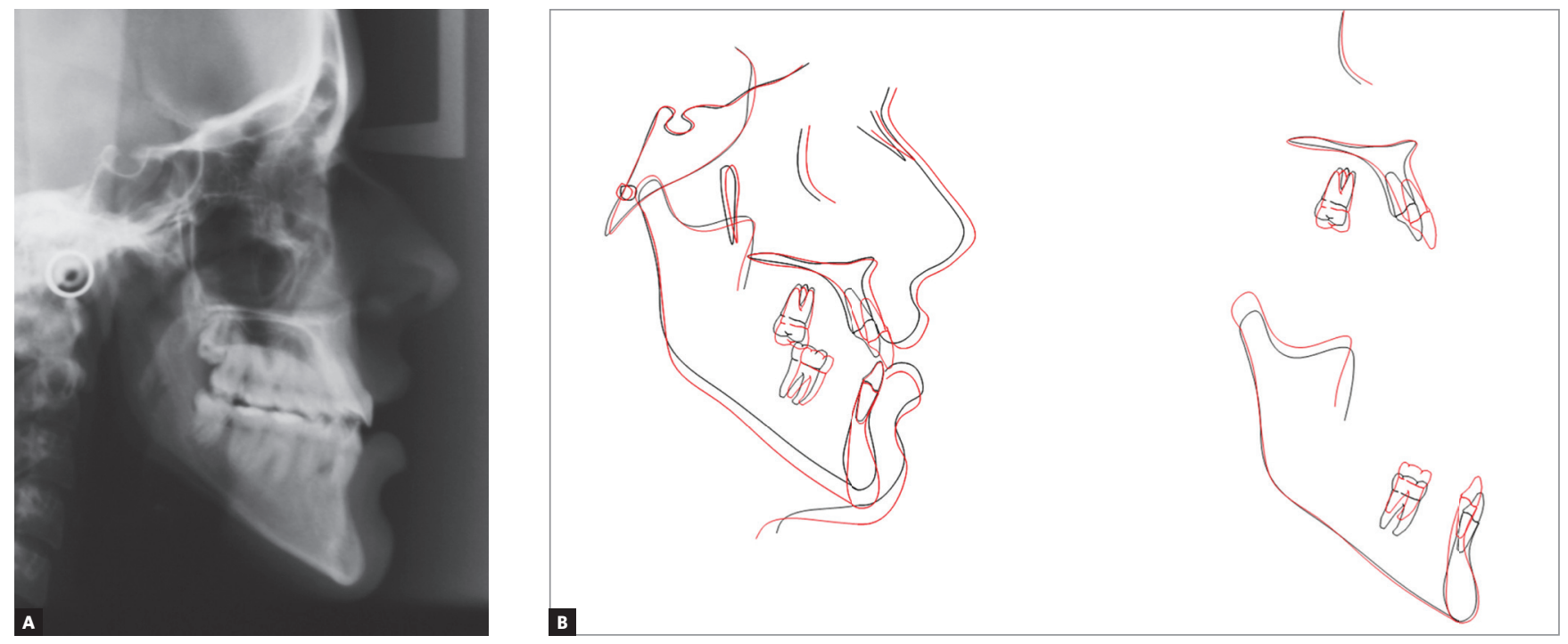

Figure 13 - Final cephalometric radiograph and superimposition of initial (black) and final (red) tracing.
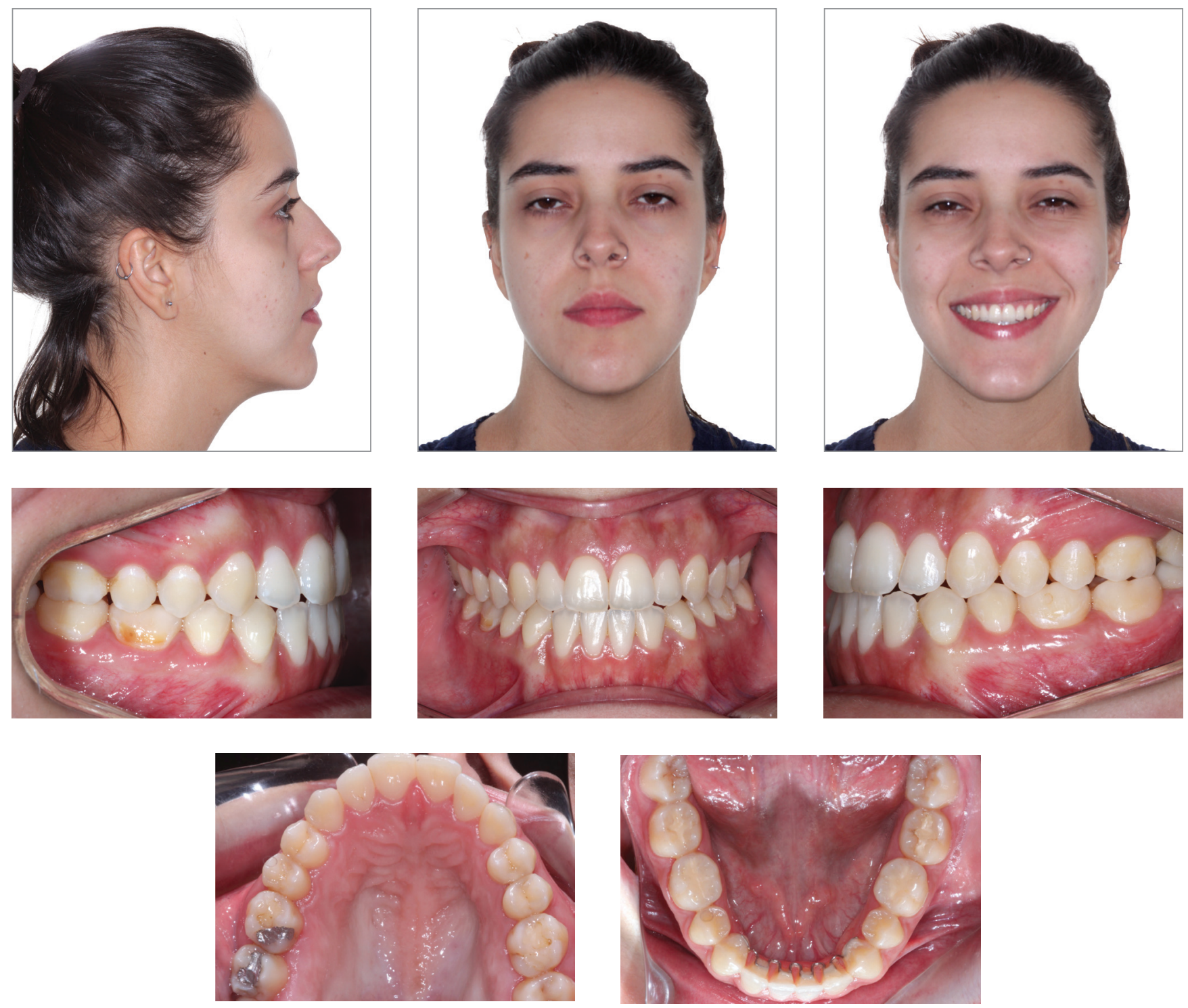

Figure 14 - Seven-years posttreatment extra- and intraoral photographs. 

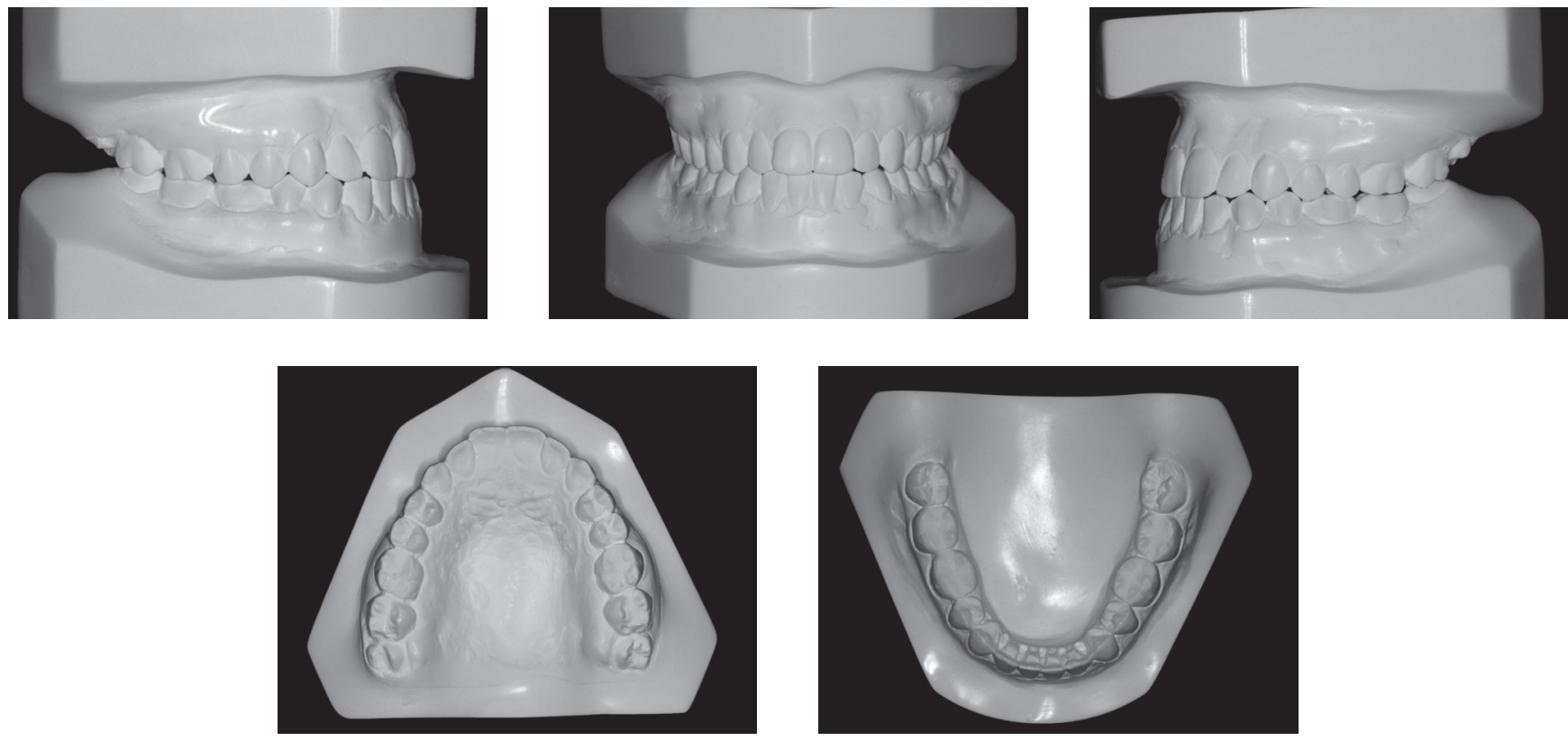

Figure 15 - Seven-years posttreatment dental models

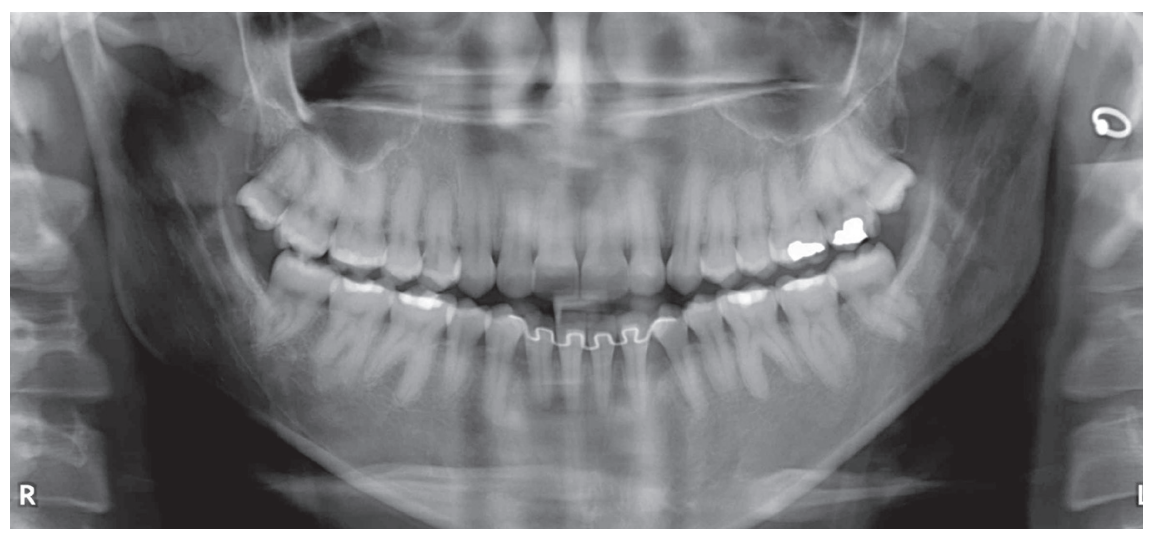

Figure 16 - Seven-years posttreatment panoramic radiograph.

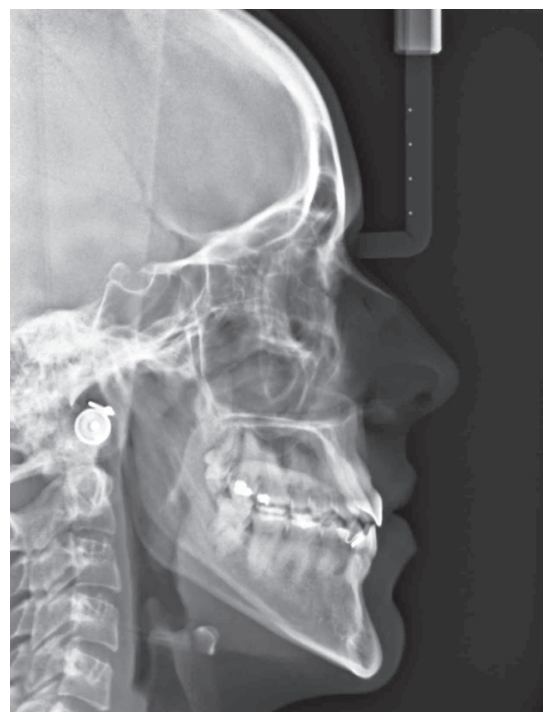

Figure 17 - Seven-years posttreatment cephalogram 

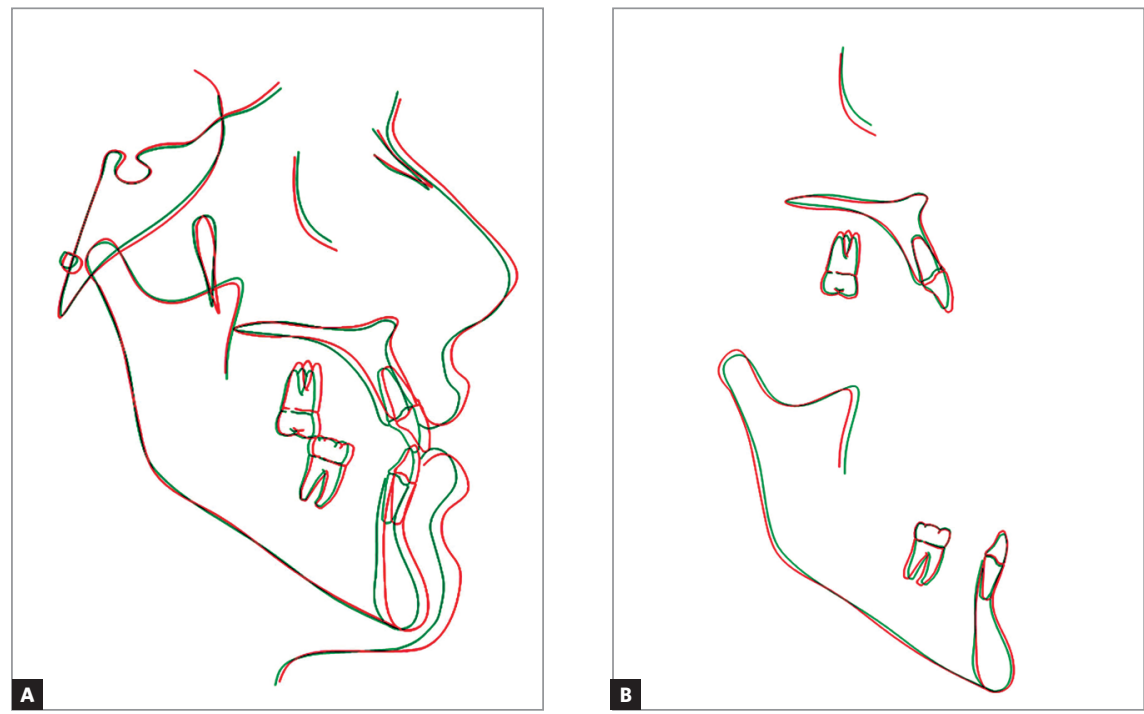

Figure 18 - Superimposition of final (red) and long-term posttreatment (green) cephalometric tracings.

Table 1 - Cephalometric status at the initial, final and posttreatment stages.

\begin{tabular}{|c|c|c|c|c|c|c|c|}
\hline & Measurements & & Normal & A & B & c & Dif. A/B \\
\hline \multirow{9}{*}{$\begin{array}{l}\text { Skeletal } \\
\text { pattern }\end{array}$} & SNA & (Steiner) & $82^{\circ}$ & $84.2^{\circ}$ & $84.8^{\circ}$ & $84.5^{\circ}$ & $-0.6^{\circ}$ \\
\hline & SNB & (Steiner) & $80^{\circ}$ & $86.1^{\circ}$ & $84.5^{\circ}$ & $83.9^{\circ}$ & $-1.6^{\circ}$ \\
\hline & ANB & (Steiner) & $2^{\circ}$ & $-1.9^{\circ}$ & $0.2^{\circ}$ & $0.5^{\circ}$ & $+1.7^{\circ}$ \\
\hline & Wits & (Jacobson) & $\begin{array}{l}\text { o } 0 \pm 2 \mathrm{~mm} \\
\mathrm{o}^{1} 1 \pm 2 \mathrm{~mm}\end{array}$ & $-9.5 \mathrm{~mm}$ & $-6.4 m m$ & $-6.7 \mathrm{~mm}$ & $+3.1 \mathrm{~mm}$ \\
\hline & Angle of convexity & (Downs) & $0^{\circ}$ & $-6.4^{\circ}$ & $-4.2^{\circ}$ & $-3.3^{\circ}$ & $+2.2^{\circ}$ \\
\hline & $Y$-axis & (Downs) & $59^{\circ}$ & $58.5^{\circ}$ & $58.3^{\circ}$ & $61^{\circ}$ & $-0.2^{\circ}$ \\
\hline & Facial angle & (Downs) & $87^{\circ}$ & $95^{\circ}$ & $95.6^{\circ}$ & $93.1^{\circ}$ & $+0.6^{\circ}$ \\
\hline & SN-GoGn & (Steiner) & $32^{\circ}$ & $38.6^{\circ}$ & $39.3^{\circ}$ & $40^{\circ}$ & $+0.7^{\circ}$ \\
\hline & FMA & (Tweed) & $25^{\circ}$ & $33.3^{\circ}$ & $32.9^{\circ}$ & $35.2^{\circ}$ & $-0.4^{\circ}$ \\
\hline \multirow{7}{*}{$\begin{array}{l}\text { Dental } \\
\text { pattern }\end{array}$} & IMPA & (Tweed) & $90^{\circ}$ & $73.1^{\circ}$ & $71.3^{\circ}$ & $75.1^{\circ}$ & $-1.8^{\circ}$ \\
\hline & 1.NA (degrees) & (Steiner) & $22^{\circ}$ & $26.3^{\circ}$ & $21.7^{\circ}$ & $18.3^{\circ}$ & $-4.6^{\circ}$ \\
\hline & 1 -NA (mm) & (Steiner) & $4 \mathrm{~mm}$ & $5.1 \mathrm{~mm}$ & $6.8 \mathrm{~mm}$ & $5.6 \mathrm{~mm}$ & $+1.7 \mathrm{~mm}$ \\
\hline & $\overline{1} . N B$ (degrees) & (Steiner) & $25^{\circ}$ & $20.2^{\circ}$ & $17.4^{\circ}$ & $21.2^{\circ}$ & $-2.8^{\circ}$ \\
\hline & $\overline{1}-\mathrm{NB}(\mathrm{mm})$ & (Steiner) & $4 \mathrm{~mm}$ & $3.7 \mathrm{~mm}$ & $4.3 \mathrm{~mm}$ & $5 \mathrm{~mm}$ & $+0.6 \mathrm{~mm}$ \\
\hline & $\frac{1}{1}$ - Interincisal angle & (Downs) & $130^{\circ}$ & $135.4^{\circ}$ & $140.7^{\circ}$ & $140^{\circ}$ & $+5.3^{\circ}$ \\
\hline & $\overline{1}-A P O$ & (Ricketts) & $1 \mathrm{~mm}$ & $3.9 \mathrm{~mm}$ & $2.2 \mathrm{~mm}$ & $2.9 \mathrm{~mm}$ & $-1.7 \mathrm{~mm}$ \\
\hline \multirow{2}{*}{ Profile } & Upper lip - S-line & (Steiner) & $0 \mathrm{~mm}$ & $-4 \mathrm{~mm}$ & $-3.2 \mathrm{~mm}$ & $-2.8 \mathrm{~mm}$ & $-0.8 \mathrm{~mm}$ \\
\hline & Lower lip - S-line & (Steiner) & $0 \mathrm{~mm}$ & $1.6 \mathrm{~mm}$ & $-0.4 \mathrm{~mm}$ & $-0.4 \mathrm{~mm}$ & $-2.0 \mathrm{~mm}$ \\
\hline
\end{tabular}




\section{FINAL CONSIDERATIONS}

The initial maxillary expansion was able to improve the transverse deficiency of the maxilla. However, maxillary protraction, following Liou's expansion protocol produced only slight improvement in the anteroposterior position of the maxilla (Table 1 and Fig 10). Perhaps patient's age was a bit advanced. ${ }^{16,17}$ Besides, not every patient responds very favorably to maxillary protraction. ${ }^{17}$

There was relative retrusion of the mandible, which was probably due to retraction of the mandibular incisors and also to the effects of the CS2000 spring and Class III elastics,18-20 (Figs 8, 9 and Table 1). The association of a slight maxillary protraction and mandibular retrusion produced improvement of the Class III anteroposterior relationship and decreased profile concavity. ${ }^{19}$ Despite the accentuated vertical growth pattern, the orthodontic mechanics did not produce a clockwise mandibular rotation. Probably the extraction mechanics helped in the vertical control. ${ }^{21}$

The negative overjet improved due to maxillary incisor protrusion and mandibular incisor lingual tipping during retraction (Table 1). Although the maxillary incisors were protruded, they also experienced palatal tipping. This demonstrates that there was excessive palatal resistant torque during Class III elastics/spring mechanics. ${ }^{2,22}$ A positive overbite was obtained consequent to extrusion of the mandibular incisors with the use of Class III elastics and vertical anterior elastics in the finishing procedures. ${ }^{2,18,22,23}$

The dentoskeletal changes provided improvement of the soft tissue profile, causing slight protrusion of the upper lip and retrusion of the lower lip, which contributed to establish a passive lip seal (Table 1 and Fig 10).

It was felt that a compensatory orthodontic treatment could provide satisfactory results in this patient because her facial esthetics was not significantly compromised and more importantly, because the patient and her parents did not want to undergo surgery. Perhaps an orthodontic-surgical approach would provide a better result. However, the patient and her parents were very satisfied with the obtained results.
The option of extracting the mandibular canines was taken because it would require less anchorage reinforcement to retract the anterior teeth. One can visualize that the first mandibular premolars were almost in a Class I relationship with the maxillary canines (Figs 1 and 7). Therefore, extracting the mandibular canines would only require incisor retraction and slight improvement of the anteroposterior discrepancy to obtain good anterior relationship. The first mandibular premolars would then replace the mandibular canines. There are no static or functional implications with this procedure. ${ }^{5}$

Evidently this treatment option also required great patient compliance in using the facemask and Class III elastics. The patient was not an excellent complier, but was satisfactory. This is the reason for the CS2000 spring have been used, especially in a time when the patient was already tired of using the Class III elastics. However, considering the obtained results, she performed well. After fixed appliances removal, she was instructed to use a chin-cup during the sleeping hours until the end of growth. ${ }^{24}$ However, she did not use it for a long time.

Despite her little compliance with posttreatment active retention, treatment has demonstrated to be very stable after 7 years (Figs 14 to 18). Her maxillary third molars erupted, but without antagonists. If they were overerupted in the next follow-ups, they would need to be extracted.

A detailed diagnosis has to be performed to provide good treatment results that also satisfies the patient and parents' needs. A thorough analysis of the occlusal, skeletal and soft tissue components has to be performed to provide the adequate treatment for each individual situation. 


\section{REFERENCES}

1. Stellzig-Eisenhauer A, Lux CJ, Schuster G. Treatment decision in adult patients with Class III malocclusion: orthodontic therapy or orthognathic surgery? Am J Orthod Dentofacial Orthop. 2002 July:122(1):27-37; discussion 37-8

2. Janson G, Souza JE, Alves FA, Andrade P Jr, Nakamura A, Freitas MR, et al. Extreme dentoalveolar compensation in the treatment of Class III malocclusion. Am J Orthod Dentofacial Orthop. 2005 Dec;128(6):787-94

3. Benyahia H, Azaroual MF, Garcia C, Hamou E, Abouqal R, Zaoui F. Treatment of skeletal class III malocclusions: Orthognathic surgery or orthodontic camouflage? How to decide. Int Orthod. 2011 June;9(2):196209

4. Poletti L, Silvera AA, Ghislanzoni LTH. Dentoalveolar class III treatment using retromolar miniscrew anchorage. Prog Orthod. 2013 May; 14(1):7.

5. Zimmer B, Gaida S, Dathe H. Compensation of skeletal Class II malocclusion by isolated extraction of mandibular teeth. J Orofac Orthop. 2016 Mar;77(2):119-28

6. Costa Pinho TM, Ustrell Torrent JM, Pinto JGC. Orthodontic camouflage in the case of a skeletal class III malocclusion. World J Orthod. 2004 Fall; 5(3):213-23.

7. Niwa K, Kushimoto K, Yamamaoto T. Mandibular first premolar teeth extraction in skeletal Class III malocclusion. Gifu Shika Gakkai Zasshi. 1990 June:17(1):330-8

8. Ruellas AC, Baratieri C, Roma MB, Izquierdo AM, Boaventura L, Rodrigues CS, et al. Angle Class III malocclusion treated with mandibular first molar extractions. Am J Dentofacial Orthop. 2012 Sept:142(3):384-92.

9. Lima E, Brum F, Mezomo M, Pasquali CE, Farret M. Orthodontic treatment of Class III malocclusion with lower extraction and anchorage with mini implants: case report. J World Fed Orthod. 2017 Mar;6(1):28-34.

10. Lin J, Gu Y. Lower second molar extraction in correction of severe skeletal Class III malocclusion. Angle Orthod. 2006 Mar;76(2):217-25.

11. Canut JA. Mandibular incisor extraction: indications and long-term evaluation. Eur J Orthod. 1996 Oct:18(5):485-9.

12. Janson G, Canto GL, Martins DR, Pinzan A, Vargas Neto J. Tratamento precoce da má oclusão de classe III com a máscara facial individualizada. Rev Dent Press Ortod Ortop Facial. 1998 Maio;3(3):41-51

13. Liou EJ, Tsai WC. A new protocol for maxillary protraction in cleft patients: repetitive weekly protocol of alternate rapid maxillary expansions and constrictions. Cleft Palate Craniofac J. 2005 Mar:42(2):121-7.
14. Barrett AA, Baccetti T, McNamara JA. Treatment effects of the light-force chincup. Am J Orthod Dentofacial Orthop. 2010 Oct:138(4):468-76.

15. Janson G, Caldas W, Garib DG. Foncatti CF. Long-term stability of Class III malocclusion nonextraction treatment. J World Fed Orthod. 2017 Mar;6(1):20-7

16. Halicioglu K, Yavuz I, Ceylan I, Erdem A. Effects of facemask treatment with and without rapid maxillary expansion in young adult subjects. Angle Orthod. 2014 Sept84(5):853-61

17. Kanekawa M, Shimizu N. Age-related changes on bone regeneration in midpalatal suture during maxillary expansion in the rat. Am J Orthod Dentofacial Orthop. 1998 Dec:114(6):646-53.

18. Lin J, Gu Y. Preliminary investigation of nonsurgical treatment of severe skeletal Class III malocclusion in the permanent dentition. Angle Orthod. 2003 Aug:73(4):401-10

19. Janson G, Freitas MR, Araki J, Franco EJ, Barros SEC. Class III subdivision malocclusion corrected with asymmetric intermaxillary elastics. Am J Orthod Dentofacial Orthop. 2010 Aug:138(2):221-30

20. Janson G, Souza J, Bombonatti R, Gigliotti M, Andrade Júnior P. Evaluation of dentoalveolar compensation in the treatment of Class III Malocclusion. J Interdiscipl Med Dent Sci. 2014 Oct;2(6):1-6.

21. Kocadereli II. The effect of first premolar extraction on vertical dimension. Am J Dentofacial Orthop. 1999 July:116(1):41-5.

22. Nakamura M, Kawanabe N, Kataoka T, Murakami T, Yamashiro T, Kamioka $\mathrm{H}$. Comparative evaluation of treatment outcomes between temporary anchorage devices and Class III elastics in Class III malocclusions. Am J Orthod and Dentofacial Orthop. 2017 June:151(6):1116-24.

23. Zimmer B, Nischwitz D. Therapeutic changes in the occlusal plane inclination using intermaxillary elastics. J Orofac Orthop. 2012 Sept:73(5):377-86

24. Janson G, Cruz KS, Henriques JFC, Freitas MR, Bombonatti R, Melucci N. Tratamento ortodôntico da Classe III, subdivisão: apresentação de um caso clínico Parte 1. Rev Dent Press Ortod Ortoped Facial. 2000 Mar;5(2):59-63

25. Jacobson A. The "Wits" appraisal of jaw disharmony. Am J Orthod. 1975 Nov:67(2):125-38

26. Steiner CC. Cephalometrics in clinical practice. Angle Orthod. 1959 Jan;29(1):8-29

27. Downs WB. The role of cephalometrics in orthodontic case analysis and diagnosis. Am J Orthod. 1952 Mar:38(3):162-82. 